\title{
Human Capital Planning of Faculties in Higher Education Institutions with Analytic Hierarchy Process Model
}

\author{
Ling Zhang ${ }^{1,2}$, Xia $\mathrm{Yu}^{3}$, Zhen Yang ${ }^{3}$, Qing $\mathrm{Du}^{3}$ \\ ${ }^{1}$ School of Pharmaceutical Science and Technology, Tianjin University, Tianjin, China \\ ${ }^{2}$ Collaborative Innovation Center of Chemical Science and Engineering, Tianjin, China \\ ${ }^{3}$ Human Resource Department, Tianjin University, Tianjin, China \\ Email: lingzhang@tju.edu.cn, duqing@tju.edu.cn
}

Received 27 September 2014; revised 26 October 2014; accepted 28 November 2014

Academic Editor: Charbel J. C. Jabbour, UNESP-Sao Paulo State University, Bauru, Brazil

Copyright (C) 2014 by authors and Scientific Research Publishing Inc.

This work is licensed under the Creative Commons Attribution International License (CC BY).

http://creativecommons.org/licenses/by/4.0/

\section{(c) (i) Open Access}

\section{Abstract}

This paper proposed a human capital planning model based on the analytic hierarchy process (AHP), with which the dimension for faculty number of each school in university could be obtained according to the performance assessment of teaching, research, and service. Pair-wise comparisons and the judgmental matrix were carried out considering the relationship between human capital and achievement on evaluation items of different schools. The convenient application of this estimating system was thoroughly discussed via a given example, which provided helpful information and reference to authority department when deciding the dimension of faculties.

\section{Keywords}

Human Capital Planning, Performance Assessment, Analytic Hierarchy Process, High Education Institutions, HR

\section{Introduction}

As part of HR management policies in most universities, the dimension for staff numbers is required to be defined based on the mission of teaching, research, and service.

Traditionally, the number of faculty positions in different school is fixed. University will release vacant faculty positions when the original academic staff retired or resigned, or when the university is going to strengthen some disciplines or develop new research areas. However, as academic faculty plays the most important role in 
development of university, university should be sensitive on human resources dimensioning, that is, which should be adjusted timely to meet the developing goal and requirement of university.

Seldom investigations have been done on how to make human capital planning in universities [1]. However several studies have been tried to determine personnel scale using different methods. For example, Campos and Melo [2] conceptualized the dimensioning of nursing staff by interviewing 5 general hospital managers and their respective nursing coordinators. Topaloglu proposed a model for scheduling emergency medicine residents [3].

In this paper, a modeling system to estimate the relatively proper faculty number in university has been proposed via analytic hierarchy process (AHP) [4]. To our knowledge, this is the first time to systematically carry out human capital planning based on the performance of university on teaching, research, and service.

\section{Method}

AHP (analytic hierarchy process) theory was proposed by Thomas. L. Saaty in 1970s, by which complex issues can be structured and analyzed using hierarchical division. In this analysis, AHP software with version 0.5.2 was used to obtain the weights of index automatically.

\subsection{Structuring of the Decision Problem}

According to the characteristics of high education, the main responsibilities of academic faculty include teaching, research, and service. However, in universities of China, almost all the services are performed as items of research; therefore, teaching and research became the goal level in this model without considering the item of service specially. After reviewing the related literature and consulting experts, criteria and alternatives levels are formulated as shown in Figure 1, and descriptions of different items are as followed.

\subsubsection{Criteria in Teaching $\left(\mathrm{B}_{1}\right)$}

- Undergraduate $\left(\mathrm{C}_{1}\right)$. For faculties the key responsibilities for undergraduate teaching include class teaching $\left(D_{1}\right)$ and undergraduate supervision on the project for graduate thesis $\left(D_{2}\right)$.

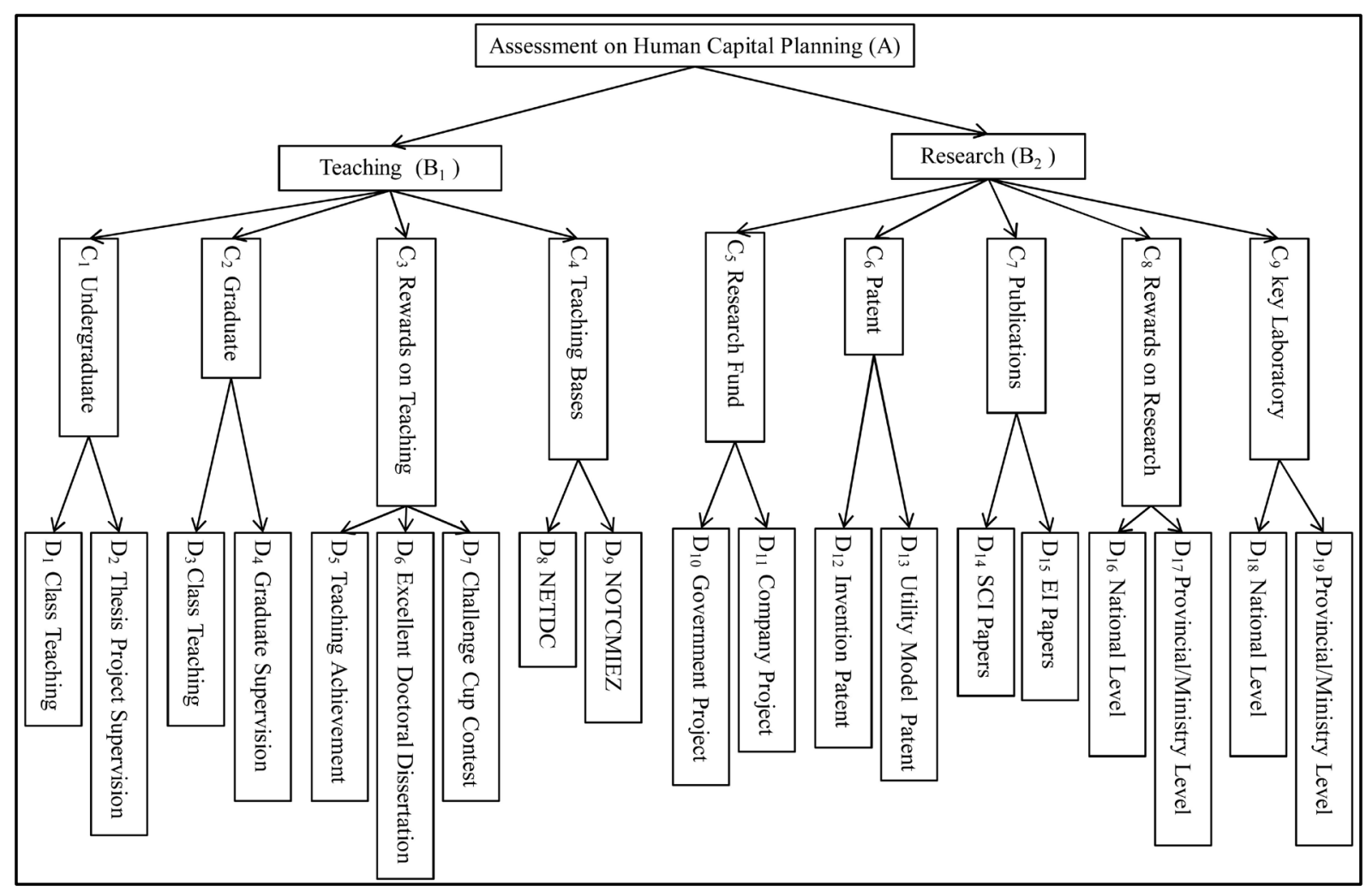

Figure 1. AHP structure. 
- Graduate $\left(\mathrm{C}_{2}\right)$. Similar to the responsibilities for undergraduate teaching, the key points for graduate teaching include class teaching $\left(\mathrm{D}_{3}\right)$ and supervising graduates for their master or Ph.D dissertation $\left(\mathrm{D}_{4}\right)$.

- Rewards on teaching $\left(\mathrm{C}_{3}\right)$. This item reveals quality of teaching, not the same purpose as the above two which show the quantity of teaching. In Chinese universities the main rewards on teaching consist of teaching achievement $\left(D_{5}\right)$, which is an assessment for teachers; excellent doctoral dissertation $\left(D_{6}\right)$, which is an evaluation for Ph.D students; and challenge cup contest $\left(D_{7}\right)$, which is a competition for bachelor students. Although the last two are rewards for students but also be shown quality of supervision, and consequently deemed important index here.

- Teaching bases $\left(\mathrm{C}_{4}\right)$. Teaching bases are divided into national and provincial/ministry level, which are approved after severe competition and subsequently become a kind of confirmation of their teaching quality, here including National Experimental Teaching Demonstration Center (NETDC) $\left(\mathrm{D}_{8}\right)$ and National Outsourcing Talents Cultivating Mode Innovation Experiment Zone (NOTCMIEZ) $\left(\mathrm{D}_{9}\right)$.

\subsubsection{Criteria in Research (B2)}

- Research fund $\left(\mathrm{C}_{5}\right)$. Research funds supported by government projects $\left(\mathrm{D}_{10}\right)$ are always believed more valuable than those supported by company projects $\left(\mathrm{D}_{11}\right)$ to academic faculties, due to the competitive nature of the application for government project. However, research funds from company projects are more deemed kind of service for or collaboration with company.

- Patent $\left(\mathrm{C}_{6}\right)$. In China, patent includes invention patent, utility model patent, and appearance design patent, among which invention patent $\left(D_{12}\right)$ and utility model patent $\left(D_{13}\right)$ are believed as important items to reveal the capability of researchers.

- Publications $\left(\mathrm{C}_{7}\right)$. Journal publication, mostly published after peer reviews, has been widely used officially or subconsciously in research performance assessment, and therefore becomes a very important index in this model. Here number of publication collected by SCI $\left(\mathrm{D}_{14}\right)$ and EI $\left(\mathrm{D}_{15}\right)$ are applied.

- Rewards on research $\left(\mathrm{C}_{8}\right)$. Similar to rewards on teaching, this item reveals quality of research, including Science and Technology Award both on National $\left(\mathrm{D}_{16}\right)$ and Provincial/Ministry $\left(\mathrm{D}_{17}\right)$ level.

- Key laboratory $\left(\mathrm{C}_{9}\right)$. Similar to teaching bases, key laboratory includes national $\left(\mathrm{D}_{18}\right)$ and provincial/ministry $\left(\mathrm{D}_{19}\right)$ level, which is approved after severe competition and subsequently become a kind of confirmation of their research capability. Here key laboratories on national level consist of State Key Laboratory, National Engineering Laboratory, National Key Cultural Relics Research Base, National Engineering Research Center, and so on. Key laboratories on provincial/ministry level are composed of Key Laboratory of Ministry of Education, Engineering Research Center of Ministry of Education, Tianjin Municipal Key Laboratory, and so on.

\subsection{Making Pair-Wise Comparisons and Obtaining the Judgmental Matrix}

Elements are compared pair-wise and judgments on comparative attractiveness of elements are captured using a rating scale (1-9 scale in traditional AHP). 13 experts including president, vice-presidents, deans, professors, and HR staffs are asked for the opinion of the rating scale with full considering the relationship between human capital and achievement on evaluation items.

\subsection{Determining the Weight}

The weights of indices of each layer are obtained using AHP software with version 0.5.2.

\section{Results and Discussion-Case Study}

Founded in 1895 as Peiyang University, Tianjin University (TU) is the oldest university in China. TU has been a National Key University since 1959 and also among the first group of universities to be included into the "211" and " 985 " projects of national investment for developing world class universities. Here, TU has been taken as an example for this case study to estimate the human capital planning of academics.

\subsection{Establishment of Calculation Model}

Two sets of AHP model has been established, considering the characteristics of different schools. They are di- 
vided with decreasing "research responsibility" and increasing "teaching responsibility": Category I—Engineering Schools, including School of Chemical Engineering, School of Mechanical Engineering, School of Civil Engineering, and so on; Category II-School of Architecture, School of Management, School of Education, School of Liberal Arts and Law, as well as School of Marxism. The matrix and weights are shown in Table 1, Table 2, respectively. Both of these two categories have 4 levels, and the main difference between them is the weight on teaching contribution and research outcome as shown followed.

Table 1. Factor weights of Category I.

\begin{tabular}{|c|c|c|c|c|c|c|}
\hline 1st hierarchy & 2nd hierarchy & Weights to 1 st & 3rd hierarchy & Weights to $1 \mathrm{st}$ & 4th hierarchy & Weights to $1 \mathrm{st}$ \\
\hline \multirow{19}{*}{ A } & \multirow{9}{*}{$\mathrm{B}_{1}$} & \multirow{9}{*}{0.5000} & \multirow{2}{*}{$\mathrm{C}_{1}$} & \multirow{2}{*}{0.6284} & $\mathrm{D}_{1}$ & 0.1347 \\
\hline & & & & & $\mathrm{D}_{2}$ & 0.0224 \\
\hline & & & \multirow{2}{*}{$\mathrm{C}_{2}$} & \multirow{2}{*}{0.1987} & $\mathrm{D}_{3}$ & 0.0373 \\
\hline & & & & & $\mathrm{D}_{4}$ & 0.0124 \\
\hline & & & \multirow{3}{*}{$\mathrm{C}_{3}$} & \multirow{3}{*}{0.1096} & $\mathrm{D}_{5}$ & 0.0200 \\
\hline & & & & & $\mathrm{D}_{6}$ & 0.0052 \\
\hline & & & & & $\mathrm{D}_{7}$ & 0.0022 \\
\hline & & & \multirow{2}{*}{$\mathrm{C}_{4}$} & \multirow{2}{*}{0.0633} & $\mathrm{D}_{8}$ & 0.0132 \\
\hline & & & & & $\mathrm{D}_{9}$ & 0.0026 \\
\hline & \multirow{10}{*}{$\mathrm{B}_{2}$} & \multirow{10}{*}{0.5000} & \multirow{2}{*}{$\mathrm{C}_{5}$} & \multirow{2}{*}{0.2972} & $\mathrm{D}_{10}$ & 0.1783 \\
\hline & & & & & $\mathrm{D}_{11}$ & 0.0446 \\
\hline & & & \multirow{2}{*}{$\mathrm{C}_{6}$} & \multirow{2}{*}{0.0654} & $\mathrm{D}_{12}$ & 0.0420 \\
\hline & & & & & $\mathrm{D}_{13}$ & 0.0070 \\
\hline & & & \multirow{2}{*}{$\mathrm{C}_{7}$} & \multirow{2}{*}{0.4473} & $\mathrm{D}_{14}$ & 0.2982 \\
\hline & & & & & $\mathrm{D}_{15}$ & 0.0373 \\
\hline & & & \multirow{2}{*}{$\mathrm{C}_{8}$} & \multirow{2}{*}{0.1526} & $\mathrm{D}_{16}$ & 0.0981 \\
\hline & & & & & $\mathrm{D}_{17}$ & 0.0164 \\
\hline & & & \multirow{2}{*}{$\mathrm{C}_{9}$} & \multirow{2}{*}{0.0375} & $\mathrm{D}_{18}$ & 0.0241 \\
\hline & & & & & $\mathrm{D}_{19}$ & 0.0040 \\
\hline
\end{tabular}

Table 2. Factor weights of Category II.

\begin{tabular}{|c|c|c|c|c|c|c|}
\hline 1st hierarchy & 2nd hierarchy & Weights to 1 st & 3rd hierarchy & Weights to 1 st & 4th hierarchy & Weights to $1 \mathrm{~s}$ \\
\hline \multirow{19}{*}{ A } & \multirow{9}{*}{$\mathrm{B}_{1}$} & \multirow{9}{*}{0.5000} & \multirow{2}{*}{$\mathrm{C}_{1}$} & \multirow{2}{*}{0.6958} & $\mathrm{D}_{1}$ & 0.2982 \\
\hline & & & & & $\mathrm{D}_{2}$ & 0.0497 \\
\hline & & & \multirow{2}{*}{$\mathrm{C}_{2}$} & \multirow{2}{*}{0.1564} & $\mathrm{D}_{3}$ & 0.0586 \\
\hline & & & & & $\mathrm{D}_{4}$ & 0.0195 \\
\hline & & & \multirow{3}{*}{$\mathrm{C}_{3}$} & \multirow{3}{*}{0.0995} & $\mathrm{D}_{5}$ & 0.0379 \\
\hline & & & & & $\mathrm{D}_{6}$ & 0.0083 \\
\hline & & & & & $\mathrm{D}_{7}$ & 0.0036 \\
\hline & & & \multirow{2}{*}{$\mathrm{C}_{4}$} & \multirow{2}{*}{0.0483} & $\mathrm{D}_{8}$ & 0.0201 \\
\hline & & & & & $\mathrm{D}_{9}$ & 0.0040 \\
\hline & \multirow{10}{*}{$\mathrm{B}_{2}$} & & \multirow{2}{*}{$\mathrm{C}_{5}$} & \multirow{2}{*}{0.2568} & $D_{10}$ & 0.1027 \\
\hline & & & & & $\mathrm{D}_{11}$ & 0.0257 \\
\hline & & & \multirow{2}{*}{$\mathrm{C}_{6}$} & \multirow{2}{*}{0.0370} & $D_{12}$ & 0.0159 \\
\hline & & & & & $D_{13}$ & 0.0026 \\
\hline & & 0,5000 & \multirow{2}{*}{$\mathrm{C}_{7}$} & \multirow{2}{*}{0.4964} & $\mathrm{D}_{14}$ & 0.2206 \\
\hline & & & & & $D_{15}$ & 0.0276 \\
\hline & & & \multirow{2}{*}{$\mathrm{C}_{8}$} & \multirow{2}{*}{0.1650} & $\mathrm{D}_{16}$ & 0.0707 \\
\hline & & & & & $D_{17}$ & 0.0118 \\
\hline & & & \multirow{2}{*}{$\mathrm{C}_{9}$} & \multirow{2}{*}{0.0449} & $\mathrm{D}_{18}$ & 0.0192 \\
\hline & & & & & $D_{19}$ & 0.0032 \\
\hline
\end{tabular}


Table 3. Evaluation scores and faculty number of school.

\begin{tabular}{ccccc}
\hline No. & School & Scores & Ratio & Faculty No. \\
\hline 1 & School A & 100.0 & 0.1192 & 212 \\
2 & School B & 95.8 & 0.1142 & 203 \\
3 & School C & 82.5 & 0.0984 & 175 \\
4 & School D & 70.1 & 0.0836 & 149 \\
5 & School E & 59.7 & 0.0712 & 127 \\
6 & School F & 58.5 & 0.0698 & 124 \\
7 & School G & 58.3 & 0.0695 & 124 \\
8 & School H & 55.2 & 0.0658 & 102 \\
9 & School I & 48.1 & 0.0573 & 93 \\
10 & School J & 43.9 & 0.0523 & 83 \\
11 & School K & 39.2 & 0.0468 & 70 \\
12 & School L & 33.1 & 0.0394 & 57 \\
13 & School M & 26.8 & 44 \\
14 & School N & 21 & 0.0320 & 43 \\
17 & School O & School P & 0.0250 & 36 \\
\end{tabular}

\subsection{Faculty Number Planning}

Relative scores of each school, which will provide ratios when calculating faculty numbers, could be obtained by each AHP model. For each item, the highest scoring school is assigned a score of 100 and scores of other schools are calculated as a percentage of the top score. The final scores for each item are summed, placed in descending order, and relative ratios are calculated according to their scores, respectively. The planning faculty numbers, with the total number (1778) of 17 schools required by the need and decided by the budget of TU, are then distributed according to the relative ratios of each school as shown in Table 3. For example, School C has a score of 82.5, taking 9.84\% of the total score (838.8), resulting an inductive faculty No. of 175 .

\section{Conclusion}

A model to estimate human capital planning of high education institutions was successfully established using AHP method. Considering the characteristics and responsibilities of different schools, 2 AHP models containing 4 criteria levels each were established. A case study of Tianjin University was discussed as an example to demonstrate this model, which could provide a good reference during human resources dimensioning process to meet the development and requirement of the goal of universities.

\section{Acknowledgements}

Ling Zhang thanks the financial support from The Ministry of education of Humanities and Social Science Research Fund Plan/Youth Fund/Self-financing project (11YJC870036) as well as Open Fund IT2012006 of the ISTIC-Thomson Reuters Joint Lab for Scientometrics Research.

\section{References}

[1] Khasawneh, S. (2010) Human Capital Planning in Higher Education Institutions. International Journal of Educational Management, 25, 534-544. http://dx.doi.org/10.1108/09513541111159040

[2] Campos, L.F. and Melo, M.R.A.C. (2007) The Dimensioning of Nursing Staff According to Nursing Coordinators: Concept, Aim and Use. Revista Latino-Americana de Enfermagem, 15, 1099-1104. 
http://dx.doi.org/10.1590/S0104-11692007000600007

[3] Topaloglu, S. (2006) A Multi-Objective Programming Model for Scheduling Emergency Medicine Residents. Computers \& Industrial Engineering, 51, 375-388. http://dx.doi.org/10.1016/j.cie.2006.08.003

[4] Saaty, T.L. (1990) How to Make a Decision: The Analytic Hierarchy Process. European Journal of Operational Research, 48, 9-26. http://dx.doi.org/10.1016/0377-2217(90)90057-I 
Scientific Research Publishing (SCIRP) is one of the largest Open Access journal publishers. It is currently publishing more than 200 open access, online, peer-reviewed journals covering a wide range of academic disciplines. SCIRP serves the worldwide academic communities and contributes to the progress and application of science with its publication.

Other selected journals from SCIRP are listed as below. Submit your manuscript to us via either submit@scirp.org or Online Submission Portal.
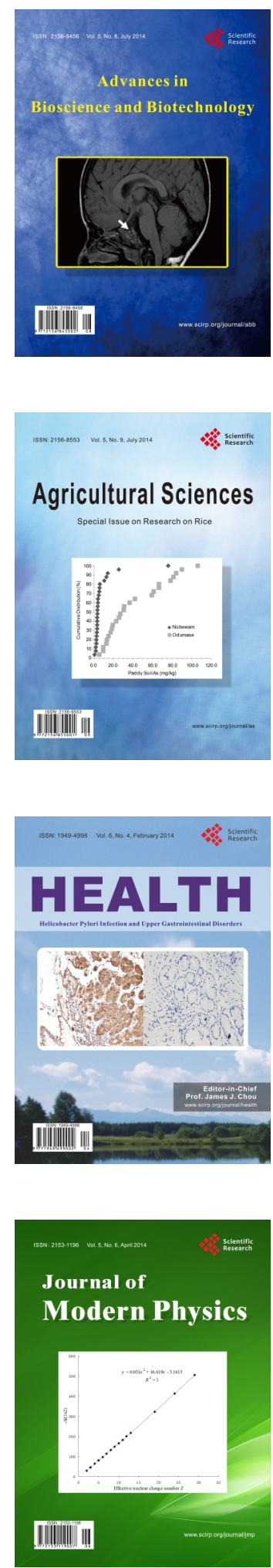
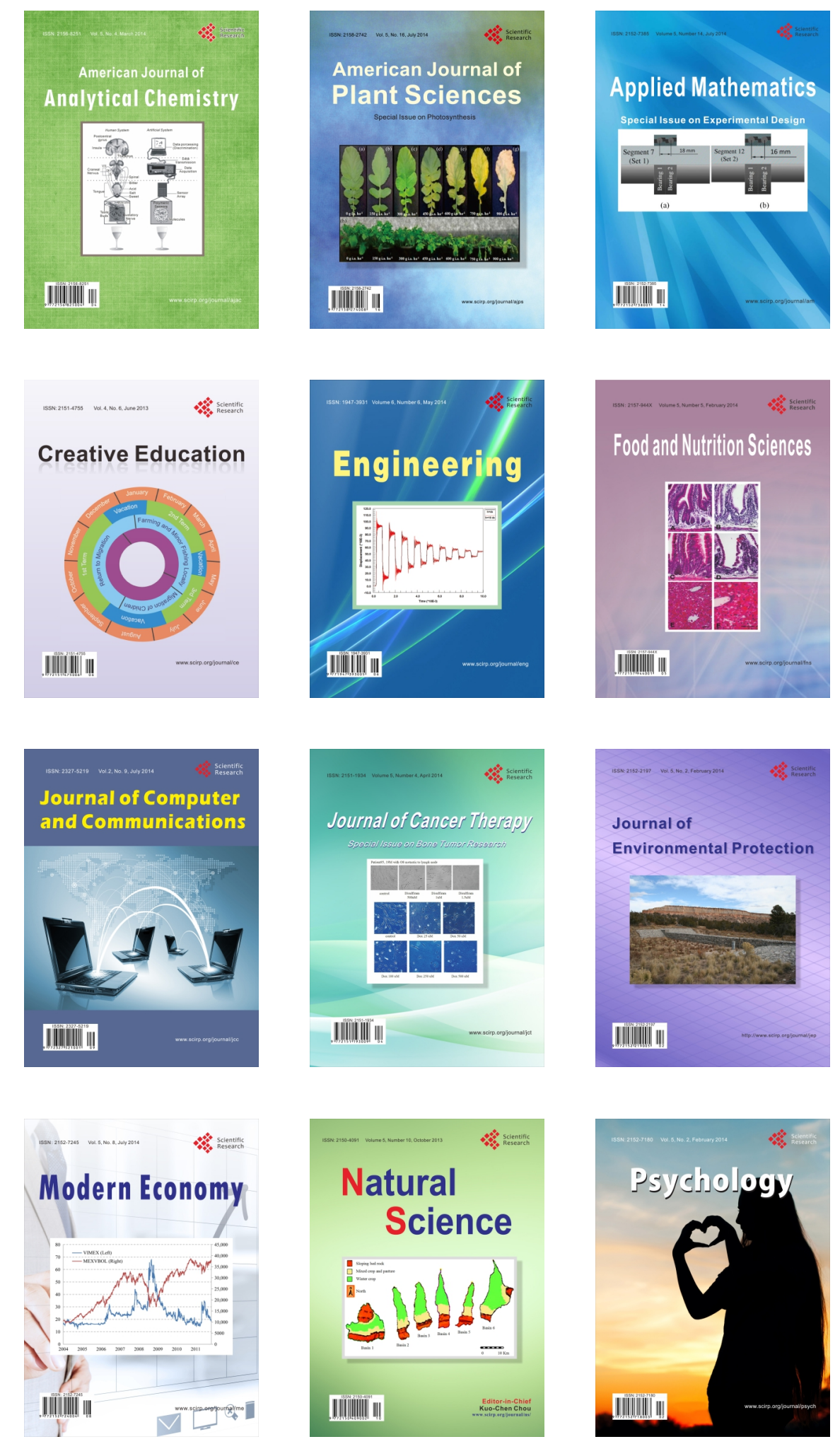